\title{
ANIMAL MODELS IN NEURODEGENERATIVE DISEASES
}

\author{
Etienne C. Hirsch
}

INSERM UMR-U679, Experimental Neurology and Therapeutics, Hôpital de la Salpêtrière, 47 Boulevard de l'Hôpital, 75013 Paris, France; University Pierre \& Marie Curie - Paris 6, Paris, France

Phone +33142162202

Fax + 33144243658

Email hirsch@ccr.jussieu.fr

Running title: Animal models in neurodegeneration

Key words: cell death, symptoms, cellular aggregation 
SUMMARY Ideally, animal models of neurodegenerative diseases should reproduce the clinical manifestation of the disease, a selective neuronal loss. In this review we will take as an example Parkinson's disease because its pathophysiology is well known and the neuronal loss well characterized. Indeed, Parkinson's disease is characterized by loss of some but not all dopaminergic neurons, a loss of some non dopaminergic neurons and alpha-synuclein positive inclusions resembling Lewy bodies. There are at least two ways to develop animal models of PD based on the etiology of the disease and consist in 1) reproducing in animals the mutations seen in inherited forms of PD; 2) intoxicating animals with putative environmental toxins causing PD. In this review we discuss the advantages and the drawbacks in term of neuroproction of the currently used models. 


\section{MAJOR CHARACTERISTICS OF ANIMAL MODELS OF EURODEGENERATIVE DISORDERS}

Neurodegenerative disorders are characterized by a slow and progressive degeneration of neurons in specific locations of the central nervous system. It is this topographical arrangement of neuronal death that accounts for the specific clinical manifestations of each disease. Indeed, a major consequence of this neuronal loss is to induce changes in the functioning of the neuronal circuits downstream to the lesions and these changes are responsible for the clinical manifestation of the disease. In this context, changes in neuronal activity in motor systems will induce motor symptoms such as those seen in Parkinson's disease (PD), Huntington disease (HD), hemiballism, etc. This concept may be extended to all kinds of symptoms and neurological disorders. Yet, most of the neurodegenerative disorders are also characterized by changes in non-neuronal cells. For instance, both an astroglial and a microglial reaction have been reported in Alzheimer's disease (AD), PD, multiple sclerosis,

etc. Last but not least, several neurogenerative disorders also display protein aggregation within neurons or glial cells. Schematically, four types of protein aggregations have been described: a) $\alpha$-synuclein accumulation in PD and other neurological disorders called synucleinopathies; b) accumulation of Tau proteins in the form of neurofibrillary tangles in neurons or glial cells in AD, progressive supranuclear palsy (PSP) and other tauopathies; c) $\mathrm{A} \beta$ peptide in extracellular plaques in $\mathrm{AD}$; and d) intranuclear inclusions made up of mutated proteins in inherited diseases characterized by an increased number of nucleotide triplets in the affected gene (for review, see Ross and Poirier 2005).

Ideally animal models of neurodegenerative disorders should reproduce all the changes specific to a given disease. Unfortunately, most of the existing models do not reproduce the full spectrum of the lesions and symptoms. This is probably why animal models of neurodegenerative disorders are poorly indicative of the efficacy of neuroprotective 
substances in humans. Since the neuronal lesions in PD are relatively specific to dopaminergic systems, this disease will be taken as an example to discuss the development of animal models of neurodegenerative disorders.

\section{ANIMAL MODELS OF PARKINSON'S DISEASE}

Parkinson's disease (PD) is characterized by a triad of symptoms, namely akinesia, rigidity and tremor. These symptoms are due to the loss of dopaminergic neurons projecting to the striatum. Yet, other dopaminergic neurons are also affected in PD, albeit to a lesser extent. Furthermore, despite the fact that degeneration of non dopaminergic neurons has been reported for almost 30 years, considerable attention has only recently come to be focussed on non dopaminergic lesions, which still represent a major limitation of current therapies (Hirsch et al. 2003). Furthermore, this dopaminergic and non dopaminergic neuronal degeneration is accompanied by the production of intraneuronal inclusions called Lewy bodies. There are at least three ways to develop animal models of PD reproducing all these characteristics. The first two are based on the etiology of the disease and consist either of reproducing in animals the mutations seen in inherited forms of the disease or of intoxicating animals with putative environmental toxins causing PD. The last method currently used, which is not exclusive of the first two, is to try to reproduce molecular or biochemical changes seen post-mortem in the brain of patients with PD. These changes include increased oxidative stress, mitochondrial dysfunction, defects in protein handling, protein accumulation, gliosis and inflammatory changes (for review, see Michel et al. 2002).

\section{HOW CAN GENETICS HELP TO DEVELOP ANIMAL MODELS OF ARKINSON'S DISEASE?}

Several genes and loci involved in inherited forms of PD have been identified during the past ten years (for review, see Gasser 2005). Yet, none of the models based on these mutations 
reproduces all the characteristics of the disease. Interestingly, a model based on $\alpha$-synuclein over-expression in the fly has been developed by Feany and co-workers. They reported reduced climbing activity in flies over-expressing the wild type or the mutated form of $\alpha$ synuclein, the presence of intracellular inclusions and neuronal degeneration. Yet, similar motor changes have been seen with mutations in genes unrelated to PD, such as those involved in an inherited form of $\mathrm{AD}$ that provokes similar behavioural changes. Furthermore, there is no definite proof that the disappearance of tyrosine hydroxylase-positive neurons is due to neuronal death as it could be the consequence of a reduced tyrosine hydroxylase expression. Transgenic mice have also been developed for $\alpha$-synuclein and other mutated genes but, so far, most of them lack the loss of dopaminergic neurons seen in PD. This has led to strategies based on gene transfer methodology using a strong promoter (prion promoter) which results in the death of dopaminergic neurons in the substantia nigra due to $\alpha$-synuclein over-expression (Kirik et al. 2002). Thus, further developments are still needed in order to develop suitable genetically based animal models of PD.

\section{HOW TO DEVELOP ANIMAL MODELS OF PARKINSON'S DISEASE BASED ON THE USE OF NEUROTOXINS}

Most of the models of PD are based on the use of a neurotoxin that mimics the effect of environmental toxins or reproduces the biochemical changes seen in PD. In line with this, animal models have been developed on the basis of oxidative stress (paraquat, 6hydroxydopamine), mitochondrial complex-1 inhibition (MPTP, rotenone, annonacine), proteasome inhibition (PSI) and proinflammatory compounds (lipopolysaccaride) (for review, see Hirsch et al. 2006). Among these potential models, complex-1 inhibition with MPTP being administered continuously in mice by an osmotic pump has recently been shown not only to induce a degeneration of dopaminergic neurons but also the formation of $\alpha$-synuclein 
and ubiquitin-positive inclusions (Fornai et al. 2005). Yet, with the exception of the MPTP model controversial results have been published. For instance, non-dopaminergic lesions have been reported in the rotenone model (Höglinger et al. 2005), whereas the model induced by proteasome inhibition could not be reproduced at all (ref). Furthermore, these models still lack the non-dopaminergic lesions seen in PD.

\section{CONCLUSIONS}

In summary, several animal models have been developed to test neuroprotective strategies in neurodegenerative disorders. However, most of them are poorly predictive of an effect in patients. There are several reasons for these poor outcomes. First, as indicated in this review, the models have to be improved so as to reproduce the full spectrum of the disease. Second, for a given disease, the etiology (inherited vs. sporadic cases) and the clinical manifestation may differ from one patient to another. Consequently, neuroprotective strategies will probably have to be adapted to the different etiologies or mechanisms of cell death for a given clinical entity. This calls for patients enrolled in neuroprotective trials to be subdivided into groups according to individual differences. Such a methodology may help to improve neuroprotective strategies, which may be effective for some patients but not others.

\section{REFERENCES}

Betarbet R, Sherer TB, MacKenzie G, Garcia-Osuna M, Panov AV, Greenamyre JT (2000) Chronic systemic pesticide exposure reproduces features of Parkinson's disease. Nat Neurosci 3: 1301-1306

Bové J, Zhou C, Jackson-Lewis V, Taylor J, Chu Y, Rideout HJ, Wu DC, Kordower JH, Petrucelli L, Przedborski S (2006) Proteasome inhibition and Parkinson's disease modeling. Ann Neurol 60: 260-264

Champy P, Höglinger GU, Feger J, Gleye C, Hocquemiller R, Laurens A, Guerineau V, Laprevote O, Medja F, Lombes A, Michel PP, Lannuzel A, Hirsch EC, Ruberg M (2004) Annonacin, a lipophilic inhibitor of mitochondrial complex I, induces nigral and striatal neurodegeneration in rats: possible relevance for atypical parkinsonism in Guadeloupe. J Neurochem 88: 63-69 
Dauer W, Przedborski S (2003) Parkinson's disease: mechanisms and models. Neuron 39: 889-909

Feany MB, Bender WW (2000) A Drosophila model of Parkinson's disease. Nature 404: 394398

Fleming SM, Salcedo J, Fernagut PO, Rockenstein E, Masliah E, Levine MS, Chesselet MF (2004) Early and progressive sensorimotor anomalies in mice overexpressing wildtype human alpha-synuclein. J Neurosci 24: 9434-9440

Fornai F, Schluter OM, Lenzi P, Gesi M, Ruffoli R, Ferrucci M, Lazzeri G, Busceti CL, Pontarelli F, Battaglia G, Pellegrini A, Nicoletti F, Ruggieri S, Paparelli A, Sudhof TC (2005) Parkinson-like syndrome induced by continuous MPTP infusion: convergent roles of the ubiquitin-proteasome system and alpha-synuclein. Proc Natl Acad Sci 102: $31413-3418$

Goldberg M, Fleming SM, Palacino JJ, Cepeda C, Lam HA, Bhatnagar A, Meloni EG, Wu N, Ackerson LC|, Klapstein GJ, Gajendiran M, Roth BL, Chesselet MF, Maidment NT|, Levine MS, Shen J (2003) Parkin-deficient mice exhibit nigrostriatal deficits but not loss of dopaminergic neurons. J Biol Chem 278: 43628-43635

Goldberg M, Pisani M, Haburcak M, Vortherms T, Kitada T, Costa C, Tong Y, Martella G, Tscherter A, Martins A, Bernardi G, Roth BL, Photos EN, Calabresi P, Shen J (2005) Nigrostriatal dopaminergic deficits and hypokinesia caused by inactivation of the familial Parkinsonism-linked gene DJ-1. Neuron 45: 489-496

Herrera AJ, Castano A, Venero JL, Cano J, Machado A (2000) The single intranigral injection of LPS as a new model for studying the selective effects of inflammatory reactions on dopaminergic system. Neurobiol Dis 7: 429-447

Höglinger GU, Feger J, Prigent A, Michel PP, Parain K, Champy P, Ruberg M, Oertel WH, Hirsch EC (2003) Chronic systemic complex I inhibition induces a hypokinetic multisystem degeneration in rats. J Neurochem 84: 491-502

Höglinger GU, Lannuzel A, Escobar-Khondiker M, Michel PP, Duyckaerts C, Feger J, Champy P, Prigent A, Medja F, Lombes A, Oertel WH, Ruberg M, Hirsch EC (2005) The mitochondrial complex I inhibitor rotenone triggers a cerebral tauopathy. J Neurochem 95: 930-939

Itier JM, Ibanez P, Mena MA, Abbas N, Cohen-Salmon C, Bohme GA, Laville M, Pratt J, Corti O, Pradier L, Ret G, Joubert C, Periquet M, Araujo F, Negroni J, Casarejos MJ, Canals S, Solano R, Serrano A, Gallego E, Sanchez M, Denefle P, Benavides J, Tremp G, Rooney TA, Brice A, Garcia De Yebenes J (2003) Parkin gene inactivation alters 
behaviour and dopamine neurotransmission in the mouse. Hum Mol Genet 12: 22772291

Kim RH, Smith PD, Aleyasin H, Hayley S, Mount MP, Pownall S, Wakeham S, You-Ten AJ, Kalia SK, Horne P, Westaway D, Lozano AM, Anisman H, Park DS, Mak TW (2005) Hypersensitivity of DJ-1-deficient mice to 1-methyl-4-phenyl-1,2,3,6tetrahydropyrindine (MPTP) and oxidative stress. Proc Natl Acad Sci USA 102: 52155220

Ling ZD, Chang Q, Tong CW, Leurgans SE, Lipton JW, Carvey PM (2004) Combined toxicity of prenatal bacterial endotoxin exposure and postnatal 6-hydroxydopamine in the adult rat midbrain. Neuroscience 124: 619-628

McCormack AL, Thiruchelvam M, Manning-Bog AB, Thiffault C, Langston JW, CorySlechta DA, Di Monte DA (2002) Environmental risk factors and Parkinson's disease: selective degeneration of nigral dopaminergic neurons caused by the herbicide paraquat. Neurobiol Dis 10: 119-127

McNaught KS, Perl DP, Brownell AL, Olanow CW (2004) Systemic exposure to proteasome inhibitors causes a progressive model of Parkinson's disease. Ann Neurol 56: 149-162

Palacino JJ, Sagi D, Goldberg M, Krauss S, Motz C, Wacker M, Klose J, Shen J (2004) Mitochondrial dysfunction and oxidative damage in parkin-deficient mice. J Biol Chem 279: 18614-18622

Park J, Lee SB, Lee S, Kim Y, Song S, Kim S, Bae E, Kim J, Shong M, Kim JM, Chung J (2006) Mitochondrial dysfunction in Drosophila PINK1 mutants is complemented by parkin. Nature 441: 1157-1161

Pycock CJ (1980) Turning behaviour in animals. Neuroscience 5: 461-514

Rockenstein E, Mallory M, Hashimoto M, Song D, Shults CW, Lang I, Masliah E (2002) Differential neuropathological alterations in transgenic mice expressing alphasynuclein from the platelet-derived growth factor and Thy-1 promoters. J Neurosci Res 68: 568-578

Rousselet E, Joubert C, Callebert J, Parain K, Tremblay L, Orieux G, Launay JM, CohenSalmon C, Hirsch EC (2003) Behavioral changes are not directly related to striatal monoamine levels, number of nigral neurons, or dose of parkinsonian toxin MPTP in mice. Neurobiol Dis 14: 218-228

Sauer H, Oertel WH (1994) Progressive degeneration of nigrostriatal dopamine neurons following intrastriatal terminal lesions with 6-hydroxydopamine: a combined 
retrograde tracing and immunocytochemical study in the rat. Neuroscience 59: 401415

Song DD, Shults CW, Sisk A, Rockenstein E, Masliah, E (2004) Enhanced substantia nigra mitochondrial pathology in human alpha-synuclein transgenic mice after treatment with MPTP. Exp Neurol 186: 158-172

Von Coelln R, Thomas B, Savitt JM, Lim KL, Sasaki M, Hess EJ, Dawson VL, Dawson TM (2004) Loss of locus coeruleus neurons and reduced startle in parkin null mice. Proc Natl Acad Sci USA 101: 10744-10749 

